\title{
Modeling nitrous acid and its impact on ozone and hydroxyl radical during the Texas Air Quality Study 2006
}

\author{
B. H. Czader ${ }^{1}$, B. Rappenglück ${ }^{1}$, P. Percell ${ }^{1}$, D. W. Byun ${ }^{1,2, \dagger}$, F. Ngan ${ }^{1, *}$, and S. Kim ${ }^{1, * *}$ \\ ${ }^{1}$ Department of Earth and Atmospheric Sciences, University of Houston, Houston, TX, USA \\ ${ }^{2}$ Air Resources Laboratory, NOAA, Silver Spring, MD20910, USA \\ * present address: Air Resources Laboratory, NOAA, Silver Spring, MD20910, USA \\ *** present address: Ajou University, Suwon, S. Korea \\ $\dagger$ deceased
}

Correspondence to: B. H. Czader (bczader@uh.edu)

Received: 14 January 2012 - Published in Atmos. Chem. Phys. Discuss.: 23 February 2012

Revised: 10 July 2012 - Accepted: 13 July 2012 - Published: 2 August 2012

\begin{abstract}
Nitrous acid (HONO) mixing ratios for the Houston metropolitan area were simulated with the Community Multiscale Air Quality (CMAQ) Model for an episode during the Texas Air Quality Study (TexAQS) II in August/September 2006 and compared to in-situ MC/IC (mistchamber/ion chromatograph) and long path DOAS (Differential Optical Absorption Spectroscopy) measurements at three different altitude ranges. Several HONO sources were accounted for in simulations, such as gas phase formation, direct emissions, nitrogen dioxide $\left(\mathrm{NO}_{2}\right)$ hydrolysis, photoinduced formation from excited $\mathrm{NO}_{2}$ and photo-induced conversion of $\mathrm{NO}_{2}$ into $\mathrm{HONO}$ on surfaces covered with organic materials. Compared to the gas-phase HONO formation there was about a tenfold increase in HONO mixing ratios when additional HONO sources were taken into account, which improved the correlation between modeled and measured values. Concentrations of HONO simulated with only gas phase chemistry did not change with altitude, while measured HONO concentrations decrease with height. A trend of decreasing HONO concentration with altitude was well captured with CMAQ predicted concentrations when heterogeneous chemistry and photolytic sources of HONO were taken into account. Heterogeneous HONO production mainly accelerated morning ozone formation, albeit slightly. Also HONO formation from excited $\mathrm{NO}_{2}$ only slightly affected $\mathrm{HONO}$ and ozone $\left(\mathrm{O}_{3}\right)$ concentrations. Photo-induced conversion of $\mathrm{NO}_{2}$ into $\mathrm{HONO}$ on surfaces covered with organic materials turned out to be a strong source of daytime HONO. Since HONO immediately photo-dissociates during
\end{abstract}

daytime its ambient mixing ratios were only marginally altered (up to $0.5 \mathrm{ppbv}$ ), but significant increase in the hydroxyl radical $(\mathrm{OH})$ and ozone concentration was obtained. In contrast to heterogeneous HONO formation that mainly accelerated morning ozone formation, inclusion of photo-induced surface chemistry influenced ozone throughout the day.

\section{Introduction}

The importance of nitrous acid (HONO) in the chemistry of the atmosphere stems from its photo-dissociation that serves as a significant source of hydroxyl radical $(\mathrm{OH})($ Lammel and Cape, 1996; Alicke et al., 2002, 2003; Kleffmann et al., 2005). OH plays a crucial role in the oxidation of volatile organic compounds (VOCs) leading to the formation of ozone, in particular in urban areas with high burden of VOCs (see for instance Mao et al., 2010).

The occurrence of HONO in the lower atmosphere can be attributed to either direct emissions (Kirchstetter et al., 1996; Kurtenbach et al., 2001) or chemical formation. Among known chemical sources of HONO is the gas-phase formation from the reaction between $\mathrm{OH}$ and nitric oxide (NO) (Pagsberg et al., 1997) and heterogeneous formation on surfaces from nitrogen dioxide $\left(\mathrm{NO}_{2}\right)$ hydrolysis (Kleffmann et al., 1998; Finlayson-Pitts et al., 2003; Yu et al., 2009). Additional nighttime formation of HONO that was not related to $\mathrm{NO}_{2}$ was reported on aqueous surfaces in the marine boundary layer by Wojtal et al. (2011). Results from laboratory 
experiments and field campaigns suggest that HONO can also be formed in photolytic processes but the exact mechanism has not yet been identified (Kleffmann et al., 2005; Kleffmann, 2007; Su et al., 2008; Sörgel et al., 2011). Zhou et al. $(2002,2003)$ point to the photolysis of nitrate $\left(\mathrm{NO}_{3}^{-}\right)$ and nitric acid $\left(\mathrm{HNO}_{3}\right)$ as a source of $\mathrm{HONO}$ while the chamber study of Rohrer et al. (2005) excluded photolysis of nitrate as a HONO precursor. The study of Su et al. (2011) points to soil nitrite as a possible daytime source of gas phase HONO while Li et al. (2012) found a correlation of the HONO source with adsorbed nitrate. George et al. (2005) and Stemmler et al. $(2006,2007)$ observed a photo-induced conversion of $\mathrm{NO}_{2}$ to $\mathrm{HONO}$ on surfaces covered with humic acid and other similar organic compounds. Several studies pointed to HONO formation initiated by the electronic excitation of $\mathrm{NO}_{2}$; however, they differ in an explanation of the exact mechanism of this process, and correspondingly, the yield of HONO formation (Crowley and Carl, 1997; Li et al., 2008, 2009; Carr et al., 2009; Amedro et al., 2011).

A number of studies reported modeling of HONO formation from different sources and its impact on ozone concentrations. Li et al. (2010) performed 3-D model simulations with the WRF-CHEM model for Mexico City in which they accounted for several HONO sources. They concluded that addition of HONO sources other than gas-phase chemistry significantly affects $\mathrm{HO}_{\mathrm{x}}\left(\mathrm{HO}_{\mathrm{x}}=\mathrm{OH}+\mathrm{HO}_{2}\right)$ in Mexico City leading to a midday average increase in $\mathrm{O}_{3}$ of about $6 \mathrm{ppb}$. Sarwar et al. (2008) performed CMAQ modeling of HONO for the north-eastern area of the US in which, in addition to the gas phase chemistry, $\mathrm{HONO}$ emissions, heterogeneous $\mathrm{HONO}$ formation involving $\mathrm{NO}_{2}$ and $\mathrm{H}_{2} \mathrm{O}$ and the photolysis of $\mathrm{HNO}_{3}$ adsorbed on surfaces were accounted for. This approach improved surface HONO predictions and resulted in an average ozone increase of $1.4 \mathrm{ppbv}$. The recent study of Wong et al. (2011) for Houston showed that during night HONO production on the surface is the major source of HONO and deposition the major removal pathway. A study of daytime HONO production for Houston indicate that there must be additional HONO sources beyond formation from reaction of $\mathrm{OH}$ and $\mathrm{NO}$ and from excited $\mathrm{NO}_{2}$ (Wong et al. 2012). Both studies for Houston were limited to the use of 1-D model that simplifies transport processes.

The Houston-Galveston-Brazoria (HGB) area has one of the highest ozone concentrations in the US often exceeding the National Ambient Air Quality Standard for ozone (Berkowitz et al., 2004; Daum et al., 2003; Wilczak et al., 2009). Since high HONO concentrations were measured in Houston during several air quality campaigns, e.g. in 2006 (Stutz et al., 2010; Ziemba et al., 2010) and thereafter repeatedly in 2009 (Wong et al., 2012) and 2010 (Rappenglück et al., 2011), it is important to evaluate the impact of HONO on ozone for this region. The present study assesses sources and losses of $\mathrm{HONO}$ and its impact on ozone and $\mathrm{HO}_{\mathrm{x}}$ formation. HONO is simulated with a three dimensional Community Multiscale Air Quality (CMAQ) model which includes
HONO gas-phase chemistry, heterogeneous chemistry, and emissions, as well as two new sources that we implemented, which are formation from electronically excited $\mathrm{NO}_{2}$ and formation from photo-induced reaction of $\mathrm{NO}_{2}$ on surfaces covered with organic materials. Of particular interest is the analysis of different HONO sources during day and nighttimes and their impact on atmospheric chemistry. The process analysis (PA) tool that provides information on how different physical and chemical processes affect simulated concentrations was utilized for that purpose. The effects of deposition, transport and chemical reactions on $\mathrm{HONO}$ as well as $\mathrm{O}_{3}$ and $\mathrm{HO}_{\mathrm{x}}$ mixing ratios are analyzed. The simulated concentrations of HONO are compared with in-situ as well as with long-path measurements at three different altitudes obtained in Houston, Texas.

\section{Model configuration}

Simulations for this study were performed with the CMAQ model version 4.7.1, released by the US Environmental Protection Agency (EPA) (Byun and Schere, 2006). For the purpose of deriving reliable boundary conditions CMAQ was run with $36 \mathrm{~km}$ grid resolution for the domain covering continental US, north Mexico, and south Canada and with $12 \mathrm{~km}$ grid resolution for the Texas domain. Current analysis is based on the simulations performed with $4 \mathrm{~km}$ grid resolution for the domain covering the HGB area. The atmosphere was divided into 23 vertical layers between the surface and $50 \mathrm{mbar}$ (around $20 \mathrm{~km}$ height). Chemical reactions were simulated with the SAPRC-99 chemical mechanism (Carter, 1990, 2000) that included aerosol and aqua chemistry (saprc99_ae5_aq). Simulations were performed for the 25 August-21 September 2006 time period that coincides with the Texas Air Quality Study II. Two days spin-up time was used to obtain realistic initial conditions.

The process analysis (PA) tool that is available in CMAQ was utilized in this work. PA provides information on the impact of different physical and chemical processes on simulated concentrations. PA consist of two parts: integrated process rate (IPR) analysis that determines contributions of emissions, overall chemical reactions and transport processes to simulated mixing ratios, and integrated reaction rate (IRR) analysis that provides information on the impact of individual chemical reactions on the concentration of simulated compounds.

Meteorological data were simulated with the Mesoscale Model, version 5 (MM5) (Grell et al., 1994). An updated land use and land cover data as described in Cheng and Byun (2008) was utilized in those simulations. To further improve meteorological variables a multi-nest grid-nudging based on Four-Dimensional Data Assimilation (FDDA) with the Texas CAMS and NOAA Meteorological Assimilation Data Ingest System (MADIS) was performed (Ngan et al., 2012). Conversion of the meteorological data to CMAQ inputs was 
performed with the Meteorological Chemistry Interface Processor (MCIP) (Byun and Schere, 2006).

Gridded emissions were derived with the Sparse Matrix Operator Kernel Emissions (SMOKE) system (Houyoux et al., 2000) using the Texas inventory, including hourlyspecific Texas Point-source Special Inventory (TPSI2006) for the year 2006, the Base5b 2007 area and non-road emissions, 2006 biogenic emissions, and mobile emissions derived from "linked based" and the High Performance Monitoring System (HPMS) data (available at: ftp://amdaftp. tceq.texas.gov/pub/HGB8H2/ei/). For SMOKE processing the Texas emission inventory was converted from the AIRS Facility Subsystem (AFS) to the Inventory Data Analyzer (IDA) format. Locations of point sources in the Lambert Conformal Conic (LCC) map projection format were converted into latitude-longitude (LL) coordinates for spatial allocation in SMOKE. The National Emission Inventory v. 2002 (NEI2002) was utilized for areas not covered by the Texas inventory.

\subsection{HONO sources}

In addition to the gas-phase HONO chemistry, the CMAQ version used in this study accounts for the heterogeneous formation of HONO on urban, leaves, and particle surfaces (Foley et al., 2009) with a reaction rate coefficient $k=5 \times$ $10^{-5} \times(S / V)\left[\mathrm{s}^{-1}\right]$ as measured by Kurtenbach et al. (2001), where $S / V$ is the ratio of a surface area to volume of air. For this study we implemented two additional photo-dependent HONO sources into CMAQ as described below.

Stemmler et al. $(2006,2007)$ showed that HONO can be formed from the photo-induced reaction of $\mathrm{NO}_{2}$ on surfaces covered with humic acid and similar organic materials. George et al. (2005) also observed photo-enhanced HONO production on solid organic compounds. These studies suggested that the uptake coefficient for reaction with organics is much larger than the one for heterogeneous reaction and that it depends on solar radiation. Enhanced photochemical production of HONO was also reported by Ndour et al. (2008) and Monge et al. (2010). Based on these studies Li et al. (2010) implemented a daytime HONO source with an uptake coefficient of $2 \times 10^{-5}$ for light intensities less than $400 \mathrm{~W} \mathrm{~m}^{-2}$ and an uptake coefficient scaled by (light intensity)/400 for solar radiation larger than $400 \mathrm{~W} \mathrm{~m}^{-2}$. We adopted this approach for CMAQ simulations for Houston, but obtained unrealistically high HONO concentrations. Therefore, contrary to Li et al. (2010) our approach does not employ a threshold value for solar radiation as we used an uptake coefficient of $2 \times 10^{-5}$ scaled by (light intensity)/900, where light intensity at local noon reaches about $900 \mathrm{~W} \mathrm{~m}^{-2}$. According to the following equation for the reaction rate coefficient:

$k=\frac{1}{8} v_{\mathrm{NO}_{2}}\left(\frac{S}{V} r_{\mathrm{g}}\right)$ where $v_{\mathrm{NO}_{2}}$ is the mean molecular speed of $\mathrm{NO}_{2}, S / V$ is the surface to volume ratio, and $r_{\mathrm{g}}$ is the reactive uptake coefficient, the reaction uptake coefficient $r_{\mathrm{g}}$ of $2 \times 10^{-5}$ resulted in a reaction rate coefficient $k$ of $1 \times 10^{-3} \times(S / V)\left[\mathrm{s}^{-1}\right]$ scaled to (light intensity / 900).

Formation of $\mathrm{HONO}$ initiated by excitation of $\mathrm{NO}_{2}$ was confirmed by several studies. Li et al. (2008) reported that the excited $\mathrm{NO}_{2}$ (indicated as $\mathrm{NO}_{2}{ }^{*}$ ) reacts with water to produce $\mathrm{HONO}$ and determined a reaction rate coefficient of $1.7 \times 10^{-13} \mathrm{~cm}^{3} \mathrm{~s}^{-1}$. Carr et al. (2009) and Amedro et al. (2011) suggested that this is a two step process involving two $\mathrm{NO}_{2}{ }^{*}$ molecules, and consequently, less efficient than the one reported by Li et al. (2008). In our study we adopted the $\mathrm{Li}$ et al. (2008) approach; therefore, our results provide an upper bound of the impact of this reaction on atmospheric chemistry. The excess energy of excited $\mathrm{NO}_{2}$ can also be released upon collision with nitrogen, oxygen, or water; therefore, these reactions were also accounted for in the model. The impact of this reaction was subject of several studies. While the modeling study of Wennberg and Dabdub (2008) show that exited $\mathrm{NO}_{2}$ chemistry causes significant ozone increase in California (up to $55 \mathrm{ppb}$ ) when modeled for a past period (1987) when still high $\mathrm{NO}_{\mathrm{x}}$ emissions were observed, Ensberg et al. (2010) obtained much smaller impact on ozone when lower $\mathrm{NO}_{\mathrm{x}}$ emissions occurring in 2005 were simulated.

HONO emissions from mobile sources, non-road sources, such as construction and lawn equipment, as well as off-road sources, such as emissions from ships, locomotives, and aircrafts were estimated based on the Kurtenbach et al. (2001) formula $\mathrm{HONO} / \mathrm{NO}_{\mathrm{x}}=8 \times 10^{-3}$.

Three simulations were performed using different HONO sources and are indicated as follows:

G - gas-phase HONO chemistry;

GEH - gas phase chemistry, HONO emissions, and HONO heterogeneous formation;

GEHP - same as GEH, but with addition of photoinduced HONO production;

\section{Results and discussion}

\subsection{Evaluation of HONO modeling}

Simulated HONO concentrations were compared with values measured in-situ by a mist-chamber/ion chromatograph (MC/IC) system at the top of the Moody Tower (60 m a.g.l.) on the University of Houston (UH) campus (Stutz et al., 2010) and are shown in Fig. 1a for simulation cases G, GEH, and GEHP. The highest HONO mixing ratios up to $2 \mathrm{ppbv}$ were measured during nighttimes and in the early mornings while daytime concentrations are much lower, but still appreciable. HONO values simulated with only gas-phase chemistry (case G) persistently show significant under prediction 

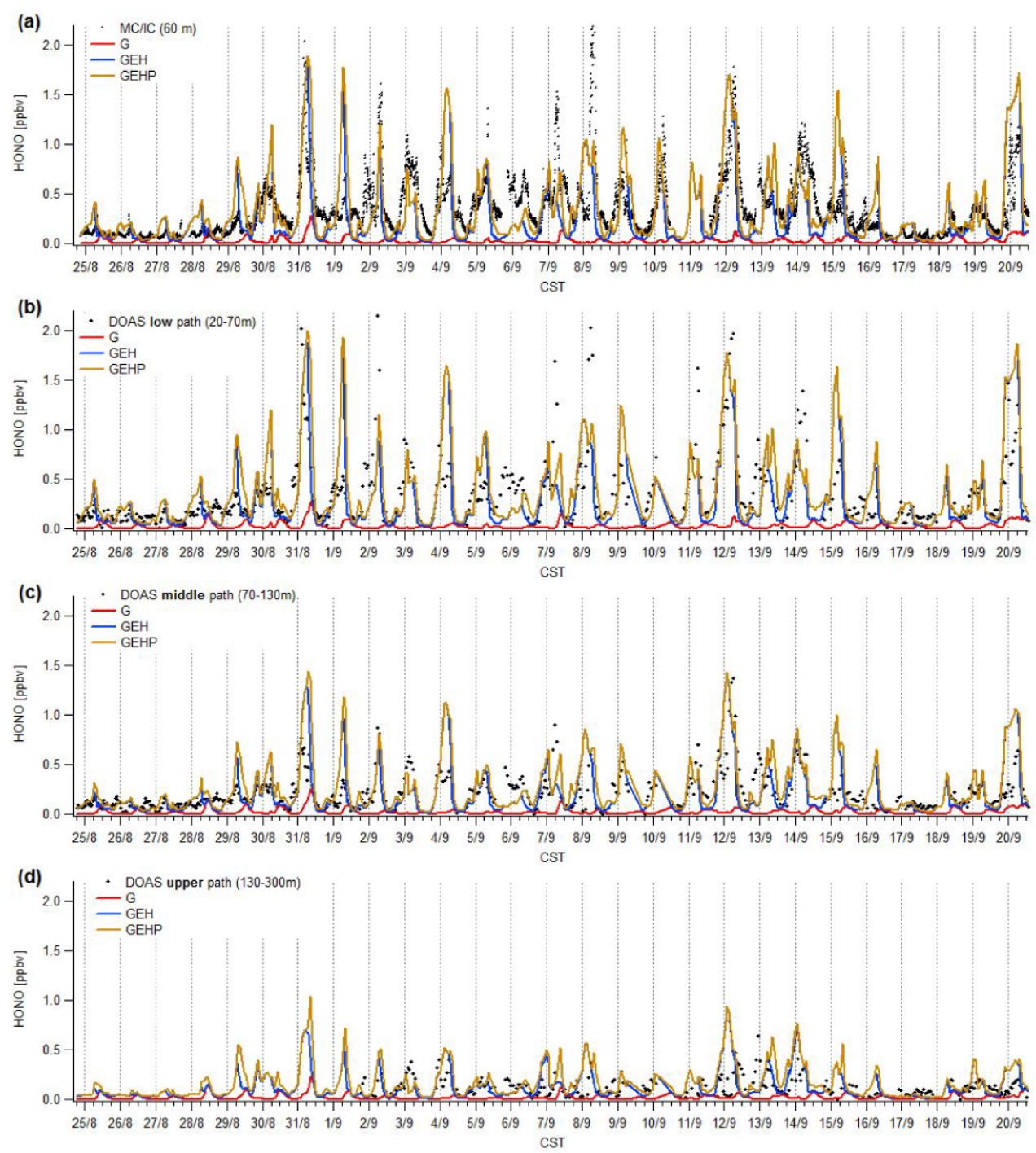

Fig. 1. Comparison of measured vs. simulated HONO time series at the UH Moody Tower for the time period 25 August-20 September 2006. Dots represent measured values, the solid lines represent CMAQ predicted concentration from G, GEH, and GEHP cases (explanation see text). Dashed vertical lines indicate midnight times. (a): Comparison with data measured in-situ by a MC/IC system at the top of the Moody Tower, at $60 \mathrm{~m}$ a.g.l. (b-d): Time series comparison of HONO measured from the Moody Tower by DOAS low light-path (b), middle light path (c), and upper path (d).

of HONO concentrations. HONO mixing ratios from GEH and GEHP cases are much closer to the observed values (e.g. 31 August, 12 and 20 September). The advantage of including photochemical HONO sources can nicely be seen on 30 August, 7, 9, and 13 September (and others) when daytime HONO values from the GEHP case are higher and closer to measurements than HONO values from the GEH case. In some cases a mismatch between observed and simulated HONO values occurs (e.g. 1 and 6 September). This is mostly related to mismatch in $\mathrm{NO}_{2}$ concentrations as discussed further below.

In order to evaluate HONO modeling for different altitudes in the urban boundary layer observational HONO data detected by Differential Optical Absorption Spectroscopy (DOAS) were utilized. These measurements were taken along different paths between the Moody Tower super site and Downtown Houston (Stutz et al., 2010). The low lightpath detected mixing ratios between $20-70 \mathrm{~m}$ height which corresponds to the first and second CMAQ model layer, the middle light-path between $70-130 \mathrm{~m}$ corresponding to the second and third layer, and the upper light-path between 130-300 m, which falls into model layers three to five. Figures $1 \mathrm{~b}-\mathrm{d}$ shows comparisons of measured and simulated HONO values. While daytime measurements show only slight dependence on altitude, HONO mixing ratios at night and early morning decrease with altitude, with maximum 
values reaching about $2 \mathrm{ppbv}$ at the low level and only about $0.5 \mathrm{ppbv}$ at the upper level. Contrary to the measured values, HONO mixing ratios from the $\mathrm{G}$ case do not show variation with height. HONO values obtained from GEH and GEHP cases correctly capture the trend towards lower nighttime and early morning mixing ratios at higher altitudes. In addition, including photolytic HONO sources in the GEHP case resulted in average 100 ppt higher daytime HONO concentrations at the low DOAS level and an average daytime increase of 50 and $30 \mathrm{ppt}$ at the middle and upper DOAS levels, respectively. Since most of the photolytic HONO production occurs by $\mathrm{NO}_{2}$ reaction at the surface, stronger increase was obtained at the lower altitudes and changes in HONO mixing ratios at higher altitudes can be explained by upward transport of HONO (see discussion in Sect. 3.2 and bottom graph in Fig. 9).

Figure 2 shows an average diurnal variation of $\mathrm{HONO}$ and $\mathrm{NO}_{2}$ based on the same data set (25 August-20 September 2006) for all simulated cases as well as MC/IC observed values. This presentation summarizes clearly the general differences in HONO model simulations. It can be seen that higher daytime values were obtained from the GEHP case, which includes photolytic HONO formation, in comparison with the GEH case, in which heterogeneous HONO production dominates HONO sources. The model tends to overpredict $\mathrm{NO}_{2}$ during nighttime and early morning which causes overprediction of simulated HONO at those times.

Figure 3 shows a time series comparison of $\mathrm{NO}_{2}$ measured by DOAS with the values simulated with the GEH case. Too high $\mathrm{NO}_{2}$ concentrations on 1 and 4 September resulted in over prediction of HONO concentrations at those times. In contrast, $\mathrm{NO}_{2}$ under prediction on 2, 7, and 8 September leads to under predictions of HONO. There may be several reasons for $\mathrm{NO}_{2}$ mismatches, such as uncertainties in emission inventory or mixing layer height, in some cases these mismatches can be related to predictions of meteorological parameters. For example, on the night of 1 September the measurements indicate calm conditions, while the model predicts strong southerly winds, causing lower modeled concentrations at the location of measurements. On 6 September the model fails to predict precipitation correctly which in turn directly affects the concentration of pollutants. The correlation coefficient between HONO values measured at the DOAS low path and those simulated with GEH case is 0.68 . However, when data points with wrong $\mathrm{NO}_{2}$ prediction were ignored and only $\mathrm{NO}_{2}$ values simulated within $70 \%$ of measured value were considered the correlation coefficient for HONO increased to 0.82 .

\subsection{Impact of $\mathrm{HONO}$ on $\mathrm{HO}_{\mathrm{x}}$ and ozone formation}

31 August and 1 September were the days with the poorest air quality index for Houston in the entire year 2006 (see also Rappenglück et al., 2008): peak 8-h averages of up to $126 \mathrm{ppbv}$ on 31 August and up to $129 \mathrm{ppbv}$ on 1 September
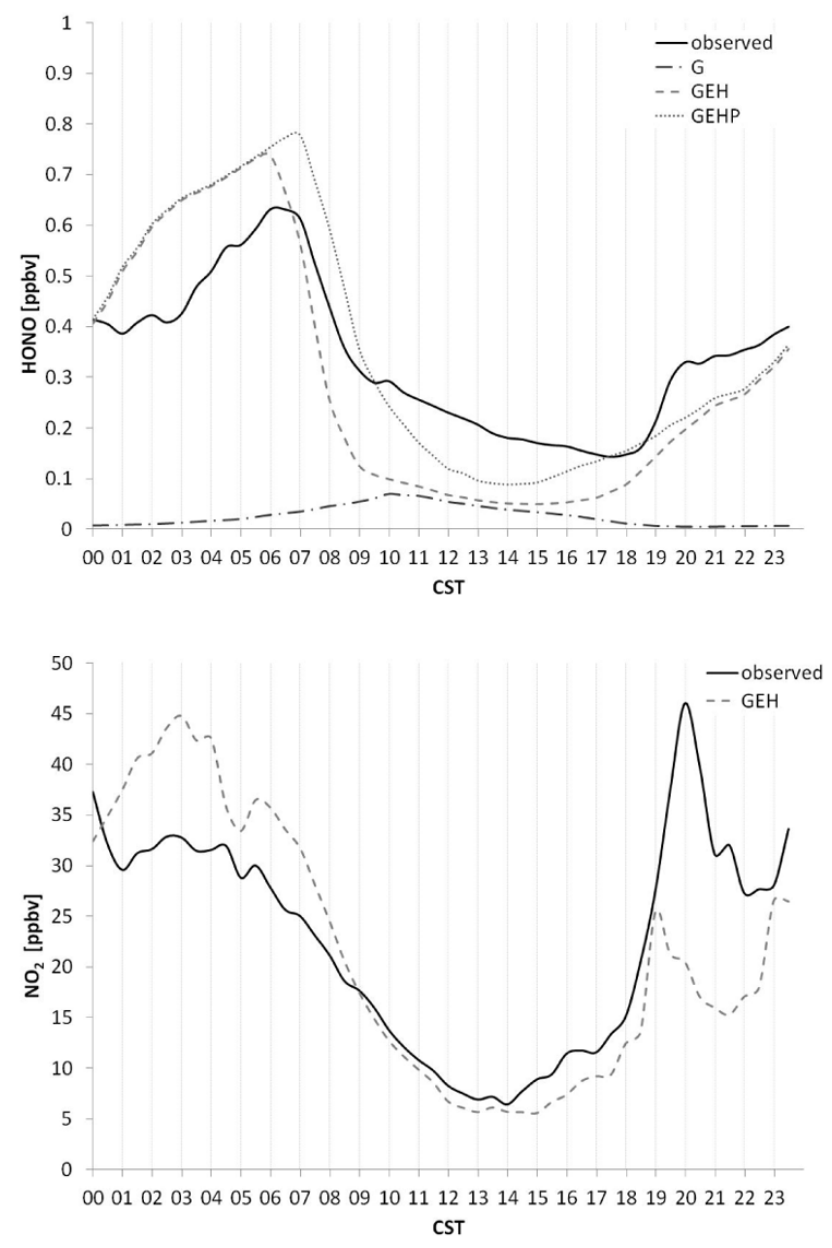

Fig. 2. Average diurnal variation of $\mathrm{HONO}$ (top) and $\mathrm{NO}_{2}$ (bottom) based on data for 25 August-20 September 2006 at the top of the Moody Tower, at $60 \mathrm{~m}$ a.g.l. Measured data obtained by MC/IC.

were measured in the Houston area. In particular for $31 \mathrm{Au}-$ gust meteorological modeling (Ngan et al., 2012) has been extensively studied. Since it is of particular interest to analyze the potential impact of $\mathrm{HONO}$ on $\mathrm{O}_{3}$ formation for ozone exceedance days most of the analysis presented here is focusing on 31 August.

Figure 4 shows a comparison of observed and modeled $\mathrm{OH}$ radical for 31 August-2 September 2006. OH was measured with the Ground-based Tropospheric Hydrogen Oxides Sensor (GTHOS) at the top of the Moody Tower (Mao et al., 2010). Modeled concentration of OH from the GEH case is similar to the G case, while on average there is $35 \%$ more $\mathrm{OH}$ from the GEHP case as compared to GEH case during morning hours $(50 \%$ more when looking only at 31 August values) and about $5 \%$ more $\mathrm{OH}$ around noon. Therefore, HONO produced in a photochemical way has much more impact on $\mathrm{OH}$ than HONO formed in a heterogeneous process. A closer look at $\mathrm{OH}$ sources from particular reactions is presented in Fig. 5. For this purpose the IRR analysis was 

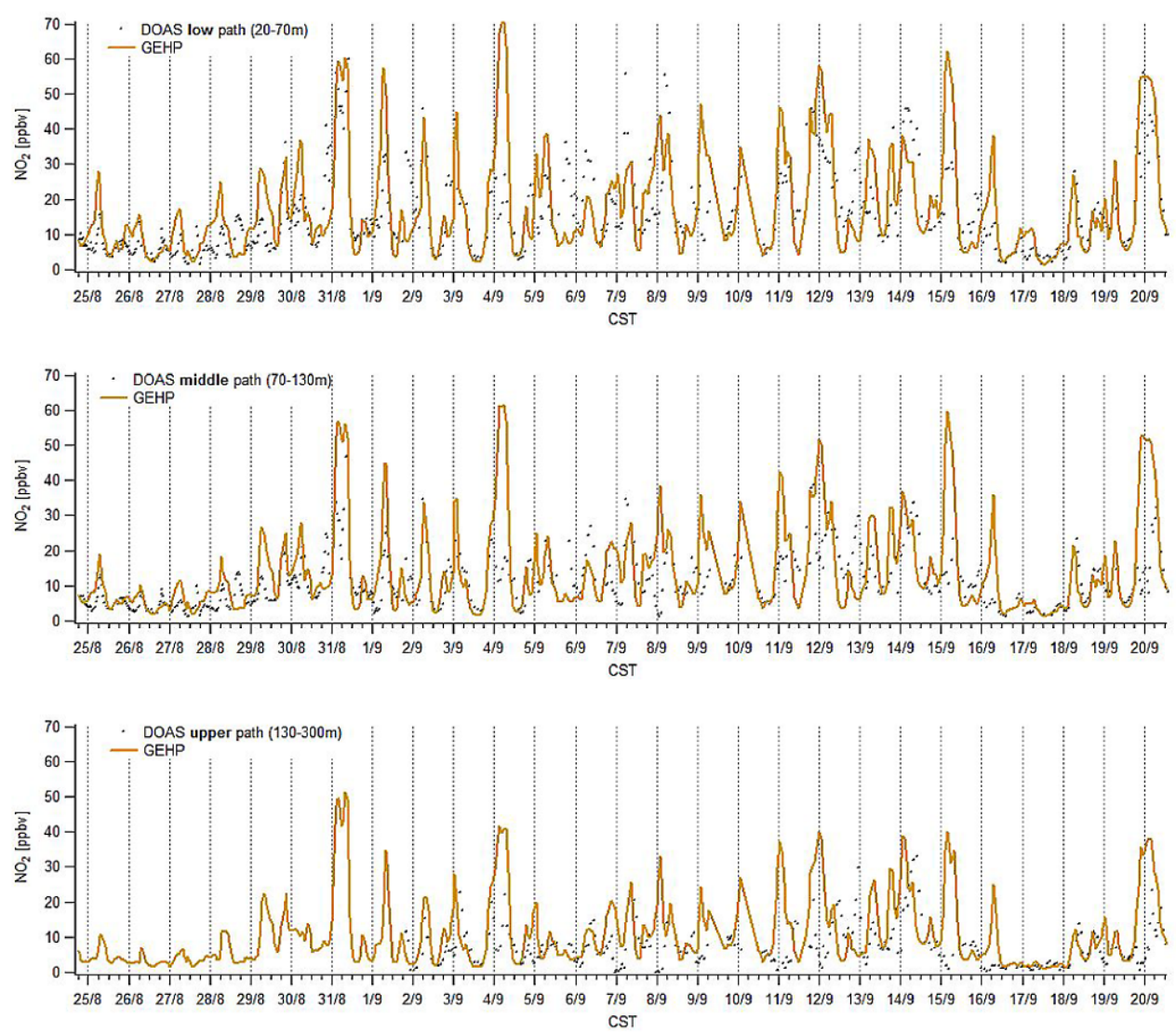

Fig. 3. Time series comparison of $\mathrm{NO}_{2}$ measured from the Moody Tower by DOAS low light-path (top graph), middle light path (middle graph), and upper path (bottom graph) with simulated mixing ratios for 25 August-20 September 2006.

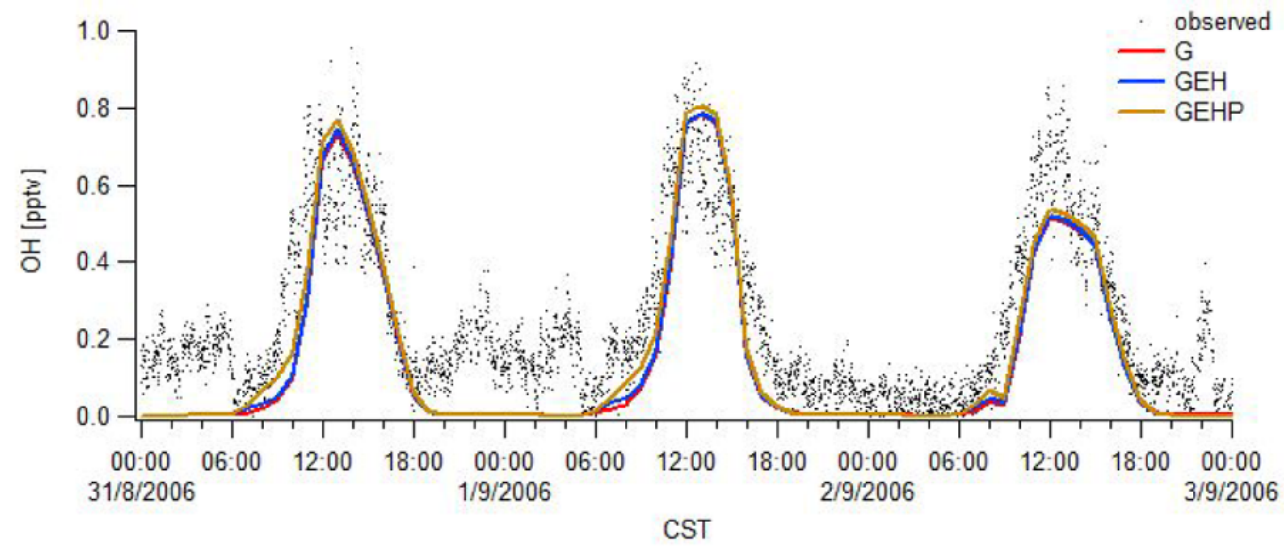

Fig. 4. Time series of observed and simulated $\mathrm{OH}$ mixing ratios at the top of the Moody Tower, at $60 \mathrm{~m}$ a.g.1., which corresponds to the second model layer.

employed. This analysis was based on data which were averaged in a box consisting of 25 horizontal cells with the middle cell corresponding to the location of the Moody Tower. The gray line in Fig. 5 shows IRR results for the GEHP case for the sum of reactions $\mathrm{HONO}+h v \rightarrow \mathrm{OH}+\mathrm{NO}$ and $\mathrm{NO}_{2}{ }^{*}+\mathrm{H}_{2} \mathrm{O} \rightarrow \mathrm{OH}+\mathrm{HONO}$ that can be interpreted as the amount of $\mathrm{OH}$ produced from these two reactions. For the GEH case the black line represents $\mathrm{OH}$ produced only from the first reaction which is photolysis of HONO. Therefore, the difference between these two cases is the amount of $\mathrm{OH}$ formed from HONO that was photo-chemically produced on surfaces. To further distinguish between the impact of $\mathrm{NO}_{2}{ }^{*}$ 


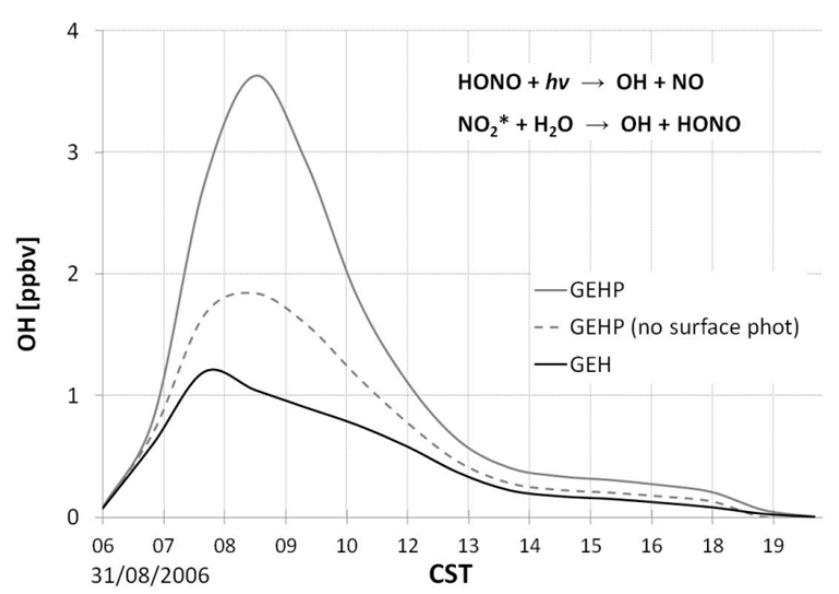

Fig. 5. $\mathrm{OH}$ production from the reaction of $\mathrm{HONO}+h v \rightarrow \mathrm{OH}+\mathrm{NO}$ and $\mathrm{NO}_{2}{ }^{*}+\mathrm{H}_{2} \mathrm{O} \rightarrow \mathrm{OH}+\mathrm{HONO}$.

on $\mathrm{OH}$ formation an additional simulation was performed in which photochemical HONO formation on surfaces covered with organic materials was not included; this simulation is indicated in the graph as "GEHP (no surface phot)". During morning hours $\mathrm{OH}$ production from the GEHP case was 2-3 times higher than production from the case without photochemical HONO formation (the GEH case) indicating that HONO produced in a photochemical way on surfaces is a significant source of $\mathrm{OH}$ in the morning. Reactions involving $\mathrm{NO}_{2} *$ contributed only about $30 \%$ to the increase in $\mathrm{OH}$.

IRR analysis was also employed to assess HONO contribution to radical production relative to other radical sources. Due to the fast chemistry between $\mathrm{OH}$ and the hydroperoxyl radical $\left(\mathrm{HO}_{2}\right)$ both radicals were considered in the analysis as $\mathrm{HO}_{\mathrm{x}}\left(\mathrm{HO}_{\mathrm{x}}=\mathrm{OH}+\mathrm{HO}_{2}\right)$. Figure 6 illustrates the diurnal variations of contributions of $\mathrm{O}_{3}, \mathrm{HCHO}, \mathrm{HONO}$ (from photolysis reaction), $\mathrm{NO}_{2}{ }^{*}$, and alkenes to the $\mathrm{HO}_{\mathrm{x}}$ budget for 31 August 2006. The results from the $\mathrm{G}$ case show that the contribution of $\mathrm{HONO}$ to the $\mathrm{HO}_{\mathrm{x}}$ formation rates in the morning (06:00-09:00 a.m. CST) is 45\%, which is low in comparison to other studies. For example, Mao et al. (2010) demonstrated that in the Houston area HONO is the major contributor to $\mathrm{HO}_{\mathrm{x}}$ in the morning. In our model analysis the morning contribution of $\mathrm{HONO}$ to $\mathrm{HO}_{\mathrm{x}}$ formation rates in Houston became dominant $(81 \%)$ when HONO emissions and heterogeneous chemistry is taken into account (GEH case). In the GEHP case $\mathrm{HONO}$ contributes $83 \%$ to $\mathrm{HO}_{\mathrm{x}}$ formation and $\mathrm{NO}_{2}{ }^{*}$ contributes $7 \%$ by directly forming $\mathrm{OH}$ radicals. The GEHP case also resulted in higher contributions throughout the day, especially between 09:00 a.m. and noon CST when HONO contribution to $\mathrm{HO}_{\mathrm{x}}$ is $52 \%(20 \%$ higher than contribution from GEH case at that time).

Figure 7 shows comparison of observed and simulated ozone concentrations at the DOAS low level for simulated time period of 25 August-20 September 2006. As it is hard to distinguish differences in ozone concentrations among sim-
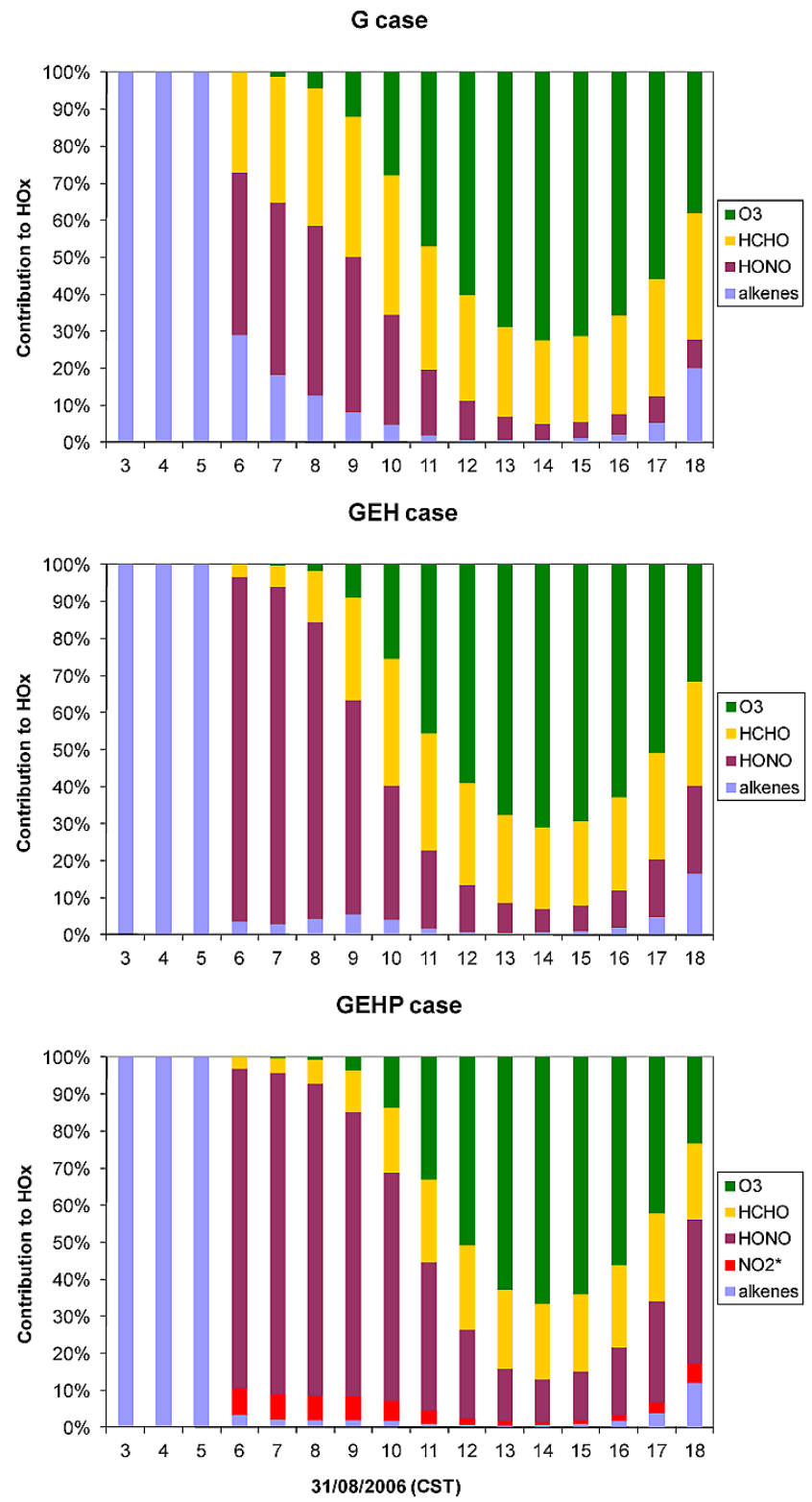

Fig. 6. Diurnal variations of contributions of $\mathrm{O}_{3}, \mathrm{HCHO}, \mathrm{HONO}$ (from photolysis reaction), $\mathrm{NO}_{2}^{*}$, and alkenes to the $\mathrm{HO}_{\mathrm{x}}$ budget for the G case (top), GEH case (middle), and GEHP case (bottom) at the top of the Moody Tower, at $60 \mathrm{~m}$ a.g.l.

ulated cases the insert in Fig. 7 shows details for 31 August. Compared to simulations with only gas phase HONO chemistry ozone concentration in the GEH case only slightly increases in the morning, but increases by about 7 ppbv and accelerates morning ozone formation for about $1-2 \mathrm{~h}$ when photo-induced HONO production is accounted for in the GEHP case. Figure 8 shows spatial differences in ozone between the GEH and G cases (left) and for the GEHP and G case (right) for 30 August, which is a day with low ozone values, compared to the 31 August 2006 case. More ozone 


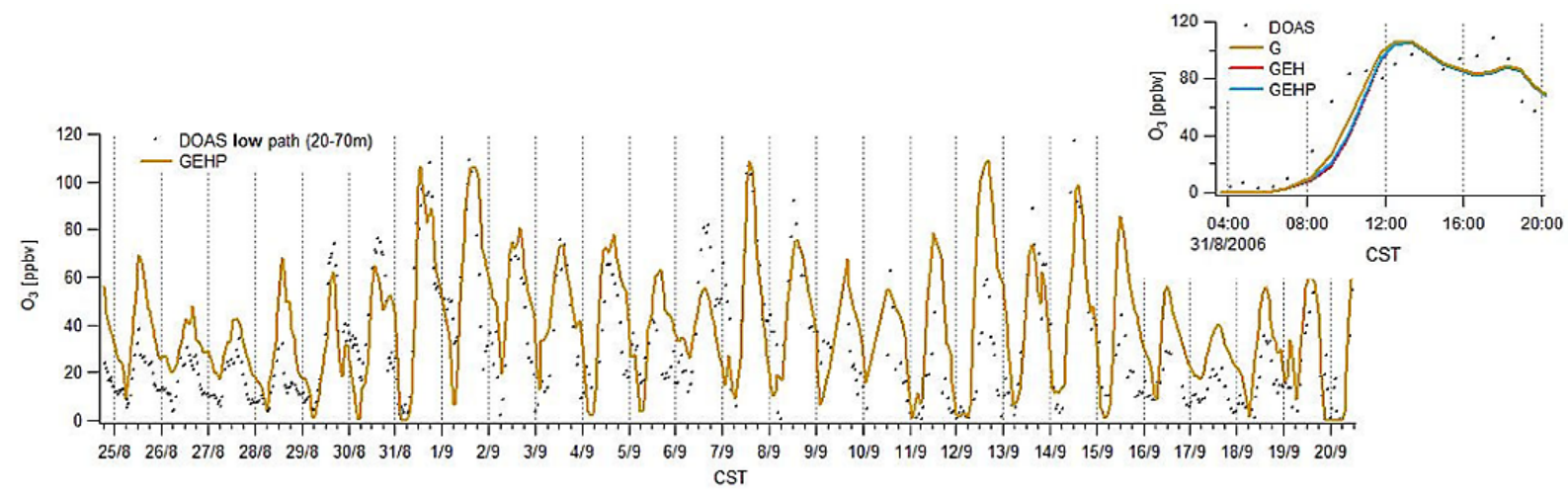

Fig. 7. Time series comparison of $\mathrm{O}_{3}$ measured from the Moody Tower by DOAS low light-path with simulated mixing ratios for 25 August20 September 2006. The insert shows a blow-up for 31 August 2006, displaying all three model simulations vs. the observed $\mathrm{O}_{3}$ data on that day.

was formed from HONO on 31 August as there were much higher $\mathrm{NO}_{2}$ mixing ratios and consequently higher $\mathrm{HONO}$ levels observed on that day as compared to 30 August. The first row of Fig. 8 shows differences in ozone for 30 August at the time of the maximum HONO impact. While ozone changes due to HONO formed in a heterogeneous way are minimal (left graph), the difference in ozone between the GEHP and G cases reach 4.3 ppbv at noon (right graph). On 31 August ozone increase from the GEH case reaches 3 ppbv at 09:00 a.m. CST while at the same time ozone differences for the GEHP case are around 8 ppbv (middle row). In the afternoon, at the time of the maximum impact of HONO on ozone mixing ratios, ozone changes in the GEH case reach only 2 ppbv and are confined to a smaller area, while in the GEHP case ozone increases up to $11 \mathrm{ppbv}$ in comparison to the $\mathrm{G}$ case (bottom row).

Even though about a tenfold increase in HONO concentration related to its heterogeneous formation and emissions was simulated with the GEH case (see Fig. 1) as compared to the $\mathrm{G}$ case, the impact of it on ozone was small. To get more insights into sources and losses of HONO the process analysis (PA) was utilized. The results of the process analysis for the G, GEH, and GEHP cases are presented in Fig. 9 and can be interpreted as contributions of processes and chemical reactions to changes in HONO mixing ratios. Processes that contribute to an increase in HONO mixing ratios are plotted with positive values, and those contributing to a decrease in HONO mixing ratio are shown with negative values. Note that the rate of change at a given hour represents change in HONO mixing ratio between that hour and the previous hour. Since most of the HONO sources occur on the surface this analysis is confined to the first model layer (0-34 ma.g.l.); horizontally data was averaged in 25 cells with the middle cell corresponding to the location of the Moody Tower. In the $\mathrm{G}$ case, the gas-phase chemistry (GAS_PROD_HONO) contributes the most to an increase in HONO mixing ratio; about $60 \%$ of produced HONO is consumed by means of photolysis and reaction with $\mathrm{OH}$ during daytime (indicated in the graph as CHEM_LOSS_HONO), about $20 \%$ is deposited to the ground, and $20 \%$ removed by transport processes. In the GEH case, $71 \%$ of HONO production is caused by heterogeneous surface chemistry (HET_HONO) during nighttime and early morning. The accumulation of HONO formed by heterogeneous chemistry and emitted during nighttime leads to the peak HONO concentration that occurs around 06:00 a.m. CST (which is 3-4 h earlier in comparison to the $\mathrm{G}$ case). At that time direct HONO emissions contribute $27 \%$. During daytime contribution from emissions increases to $50 \%$, while heterogeneous and gas formation contributes $31 \%$ and $19 \%$, respectively. The main removal of HONO from the surface layer is through upward transport (VTRAN_HONO) that contributes $77 \%$ to nighttime and $65 \%$ to daytime reduction in HONO concentration. Dry deposition removes $23 \%$ and $12 \%$ of HONO during nighttime and daytime, respectively. $24 \%$ of daytime $\mathrm{HONO}$ reacts to form $\mathrm{OH}$. Although dry deposition and vertical transport are significant HONO removal processes during nighttime, the production of HONO is higher leading to a net increase of HONO concentration that result in the morning peak. After sunrise photochemical reactions add to the removal of HONO resulting in a decrease of HONO concentration. There are two additional pathways of photochemical HONO production in the GEHP case, these are photochemical formation on surfaces covered with organic material ( $\left.h v_{-} \mathrm{SF}_{-} \mathrm{HONO}\right)$ and formation from excited $\mathrm{NO}_{2}$ $\left(h v \_\mathrm{NO}_{2} * \mathrm{HONO}\right)$. Although we used the largest reaction coefficient for $\mathrm{HONO}$ formation from excited $\mathrm{NO}_{2}$ it resulted in small amount of HONO produced by this pathway, which is even less than that from gas phase chemistry, being negligible compared with other HONO production mechanisms. The photochemical formation on the surfaces has a major contribution of $61 \%$ to HONO production during daytime. This production is overtaken mainly by vertical transport and chemical reactions leading to a net decrease in daytime 
$\mathrm{O} 3(\mathrm{GEH})-\mathrm{O}$ (G)

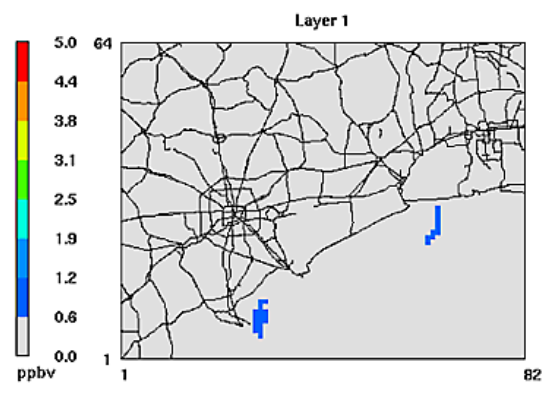

Min= -0.4 at (16.7). Max $=\quad 1.0$ at (29.11)

O3 (GEH) - O3 (G)

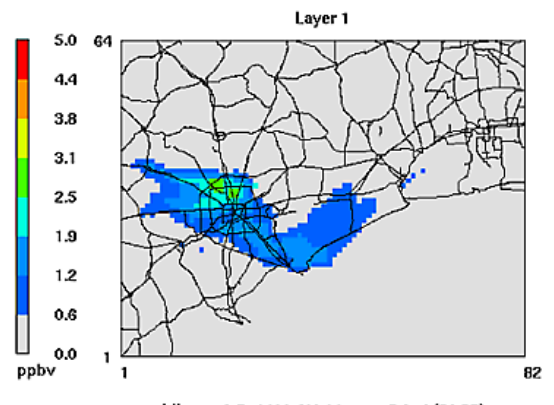

$\mathrm{O} 3(\mathrm{GEH})-\mathrm{O} 3(\mathrm{G})$

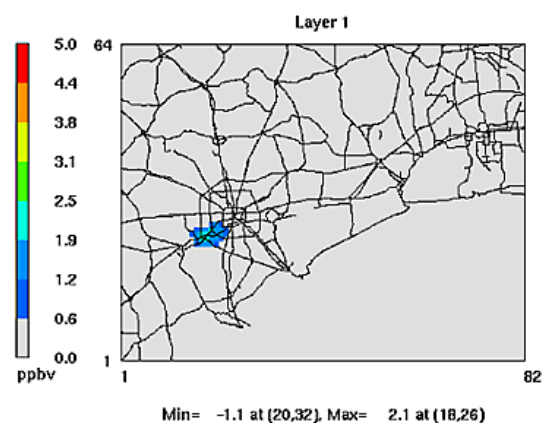

O3 (GEHP) - O3 (G)

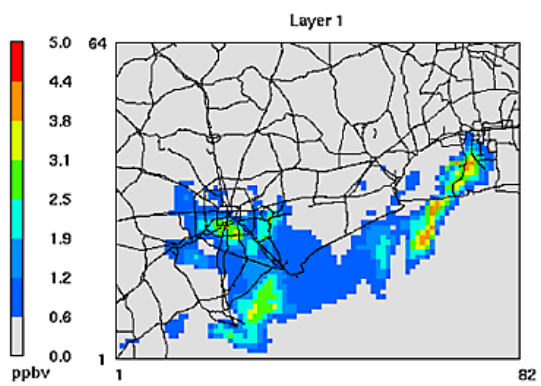

Min $=-0.2$ at (75.29). Max $=4.3$ at $(64.25)$

O3 (GEHP) - O3 (G)

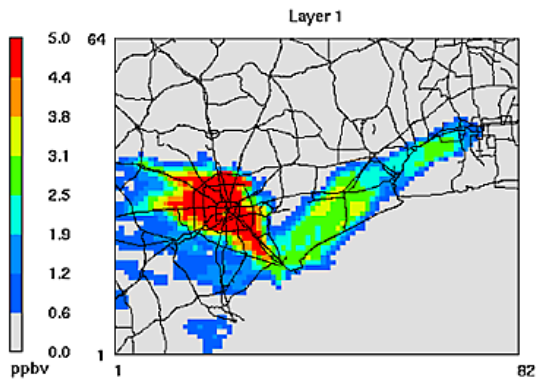

Min- -0.3 at $(8,42)$ Max- $\quad 7.9$ at $(21,35)$

O3 (GEHP) - O3 (G)

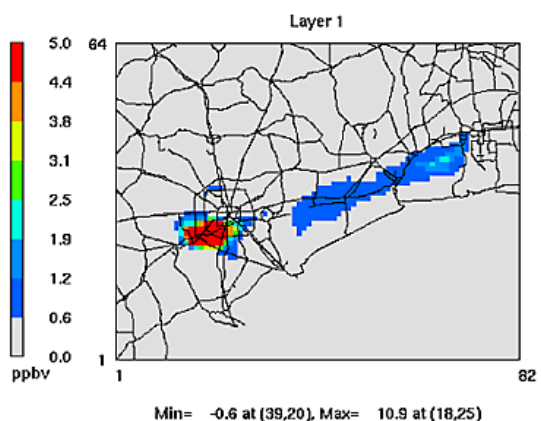

Fig. 8. Differences in surface ozone simulations between GEH-G case (left) and GEHP-G case (right) for 30 August at noon (top row), 31 August 2006 at 09:00 a.m. CST (middle row) and 01:00 p.m. CST (bottom row).

HONO mixing ratios. High removal by vertical transport can be explained by the fact that diffusion between a cell and a neighboring cell is proportional to the concentration gradient between those cells. Since the extra HONO in the GEHP case is added just in layer 1 , then that increases vertical diffusion out of layer 1. HONO chemical loss (CHEM LOSS_HONO) immediately after sunrise is more significant in the GEHP case than the GEH case. About twice as much HONO photodissociates in the GEHP case producing twice as much $\mathrm{OH}$ and $\mathrm{NO}$ as compared to the GEH case. As previously shown, this additional $\mathrm{OH}$ resulted in higher $\mathrm{OH}$ and $\mathrm{O}_{3}$ mixing ratios in the GEHP case (see Figs. 5, 7, and 8). Figure 10 shows contributions of processes and chemical reactions to changes in HONO mixing ratios for the second model layer. Because the total vertical transport is a difference between HONO transported in from layer 1 and moved out to layer 3; therefore, it is much smaller than in layer 1 . From the amount of HONO that was brought in from layer 1 and used in chemical reactions in layer 2 we estimated the amount of HONO that is moved upward to the next layer (orange dashed line). This shows that a significant amount of HONO is moving upward as vertical diffusion continues to remove the extra HONO from layer 2 redistributing it to all the layers in the PBL. This removal of HONO from layer 2 makes the increase in concentration relatively small at that level as seen in Fig. 1. 


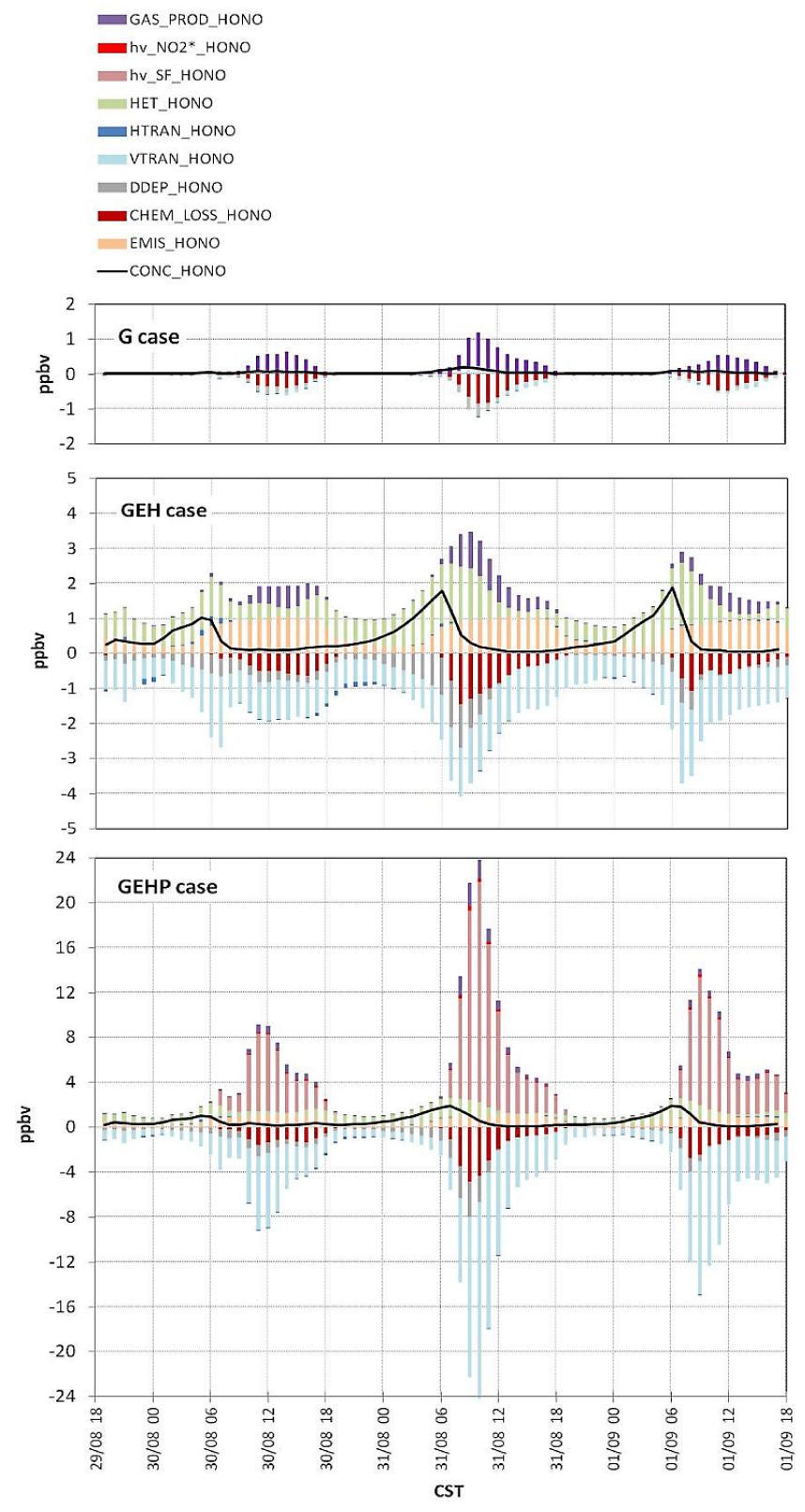

Fig. 9. HONO mixing ratio (black line) in ppbv and contribution of different processes to changes in HONO mixing ratios (columns) for G case (top), GEH case (middle), and GEHP case (bottom) in the first model layer (0-34 $\mathrm{m}$ a.g.1.). Note that the scale is different in the graphs. GAS_PROD_HONO represents $\mathrm{OH}+\mathrm{NO}$ reaction producing $\mathrm{HONO}, h \nu_{-} \mathrm{NO}_{2}{ }_{\text {_HONO }}$ is $\mathrm{HONO}$ formed from excited $\mathrm{NO}_{2}, h v_{-}$SF_HONO-is photochemical production of $\mathrm{HONO}$ on surfaces, HET_HONO represents change in HONO mixing ratio due to heterogeneous chemistry, VTRAN_HONO-vertical transport, HTRAN_HONO-horizontal transport, DDEP_HONO-dry deposition, CHEM_LOSS_HONO-oss of HONO by gas phase chemical reactions, EMIS_HONO-emissions.

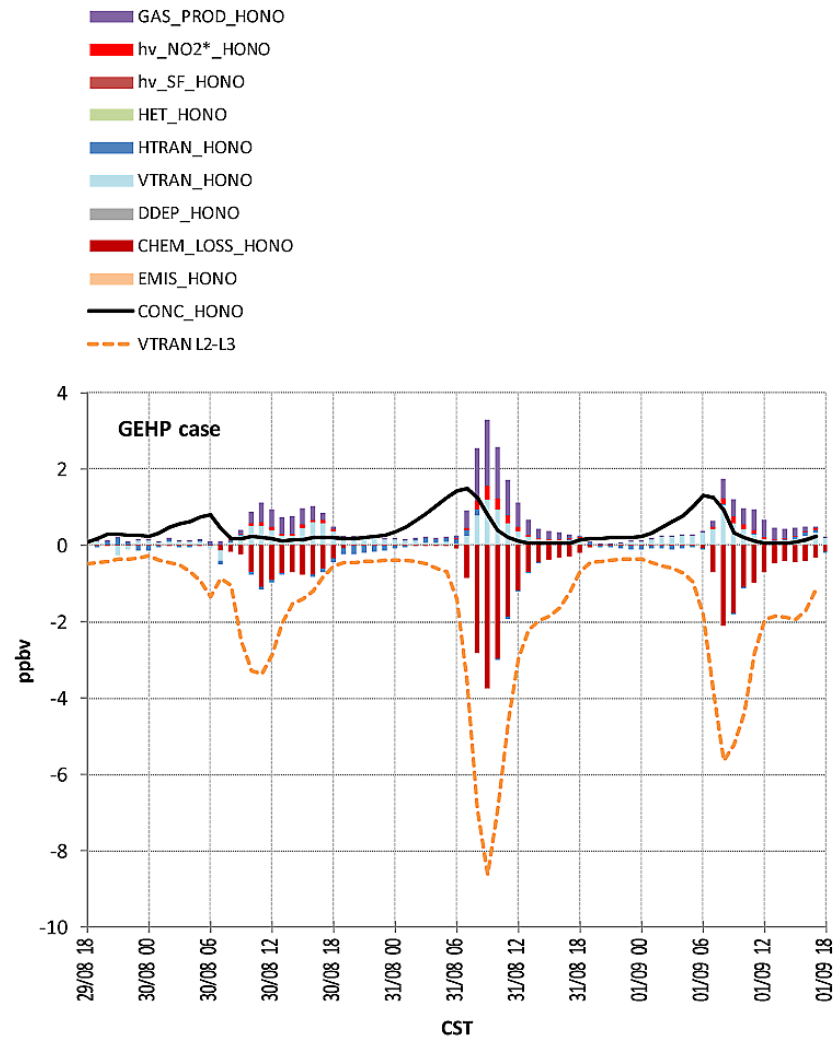

Fig. 10. The same as Fig. 9 but for the model layer 2, which is between 34-85 m a.g.l. "VTRAN L2-L3" represents HONO transported upward from layer 2 to the next model layer.

\section{Conclusions}

CMAQ simulations of HONO that included several sources of $\mathrm{HONO}$ were performed and compared with $\mathrm{MC} / \mathrm{IC}$ measured values at the Moody Tower and DOAS measurements at three altitudes. In addition, source and losses for HONO as well as the impact of its different sources on $\mathrm{HO}_{\mathrm{x}}$ and $\mathrm{O}_{3}$ were examined.

Accounting for additional HONO production (e.g. heterogeneous HONO formation) as compared to gas-phase formation resulted in about a tenfold increase in the morning HONO concentrations causing improved correlation between modeled and measured values. Also, for the first time a 3-D chemistry transport model such as CMAQ could be to a large extent successfully validated against vertically resolved HONO measurements during day and nighttime, and was able to capture correctly a trend of decreasing HONO concentration with altitude. Since $\mathrm{NO}_{2}$ is a precursor of $\mathrm{HONO}$ the mismatches in $\mathrm{NO}_{2}$ modeling directly influence $\mathrm{HONO}$ predictions. The correlation between measured and simulated $\mathrm{HONO}$ values increased significantly when data points with wrong $\mathrm{NO}_{2}$ prediction were ignored and only $\mathrm{NO}_{2}$ values simulated within $70 \%$ of the measured value were considered. 
Heterogeneous $\mathrm{HONO}$ production is a major source of HONO during nighttime leading to HONO accumulation and early morning peak concentration of up to 2 ppbv. Since HONO dissociation at that time is less important than deposition and vertical transport, heterogeneous HONO production only slightly increases concentrations of $\mathrm{OH}$ and $\mathrm{O}_{3}$ (up to 3 ppbv ozone increase). The implementation of additional photo-dependent HONO sources, in particular HONO formation from the photo-induced reaction of $\mathrm{NO}_{2}$ on surfaces covered with humic acid and similar organic materials, only resulted in an increase in HONO mixing ratios of at most $0.5 \mathrm{ppbv}$. However, process analysis shows that actually much more HONO was produced, but was quickly transported upward and dissociated, which resulted in doubled morning production of hydroxyl radical and an ozone increase of up to $11 \mathrm{ppbv}$. In contrast to heterogeneous HONO formation that mainly accelerates morning ozone formation, inclusion of HONO photochemical sources influences ozone throughout the day, affecting its peak concentration.

Although daytime HONO formation mechanisms may not be understood in all details and the implementation of it to the model is based on many assumptions and simplifications, for example the estimation of urban surfaces or uncertainties in the uptake coefficient, this paper demonstrates that photochemical HONO formation can be a strong source of daytime $\mathrm{HONO}$ that directly impacts $\mathrm{OH}$ mixing ratios and peak ozone concentrations while nighttime and early morning HONO production by means of $\mathrm{NO}_{2}$ hydrolysis greatly affects the HONO morning peak concentration but only slightly increases hydroxyl radical and ozone concentrations.

Acknowledgements. The authors would like to thank the Houston Advanced Research Center (HARC) for support. Observational DOAS data provided by Jochen Stutz, UCLA and MC/IC data provided by Jack Dibb, UNH. OH data provided by Bill Brune, Penn State University.

Edited by: A. Hofzumahaus

\section{References}

Alicke, B., Platt, U., and Stutz, J.: Impact of nitrous acid photolysis on the total hydroxyl radical budget during the limitation of oxidant production/Pianura Padana Produzione di Ozono study I Milan, J. Geophys. Res., 107, 8196, doi:10.1029/2000JD000075, 2002.

Alicke, B., Geyer, A., Hofzumahaus, A., Holland, F., Konrad, S., Pätz, H. W., Schäfer, J., Stutz, J., Volz-Thomas, A., and Platt, U.: $\mathrm{OH}$ formation by HONO photolysis during the BERLIOZ experiment, J. Geophys. Res., 108, 8247, doi:10.1029/2001JD000579, 2003.

Amedro, D., Parker, A. E., Schoemaecker, C., and Fittschen, C.: Direct observation of $\mathrm{OH}$ radicals after $565 \mathrm{~nm}$ multi-photon ex- citation of $\mathrm{NO}_{2}$ in the presence of $\mathrm{H}_{2} \mathrm{O}$, Chem. Phys. Lett., 513, 12-16, doi:10.1016/j.cplett.2011.07.062, 2011.

Berkowitz, C. M., Jobson, T., Jiang, G., Spicer, C. W., and Doskey, P. V.: Chemical and meteorological characteristic associated with rapid increases of $\mathrm{O}_{3}$ in Houston, Texas, J. Geophys. Res., 109, D10307, doi:10.1029/2003JD004141, 2004.

Byun, D. and Schere, K. L.: Review of the Governing Equations, Computational Algorithms, and Other Components of the Models-3 Community Multiscale Air Quality (CMAQ) Modeling System, Appl. Mech. Rev., 59, 51-77, 2006.

Carr, S., Heard, D. E., and Blitz, M. A.: Comment on "Atmospheric Hydroxyl Radical Production from Electronically Excited $\mathrm{NO}_{2}$ and $\mathrm{H}_{2} \mathrm{O}$ ", Science, 324, 336b, doi:10.1126/science.1166669, 2009.

Carter, W. P. L.: A Detailed Mechanism for the Gas-Phase Atmospheric Reactions of Organic Compounds, Atmos. Environ., 24, 481-518, 1990.

Carter, W. P. L.: Documentation of the SAPRC-99 chemical mechanism for VOC reactivity assessment, Final Report to the California Air Resources Board, Contracts 92-32 and 95-308, Riverside, CA, available at: http://www.cert.ucr.edu/ $\sim$ carter/absts. htm\#saprc99, 2000.

Cheng, F.-Y. and Byun, D. W.: Application of high resolution land use and land cover data for atmospheric modeling in the Houston-Galveston metropolitan area, Part I, Meteorological simulation results, Atmos. Environ., 42, 7795-7811, 2008.

Crowley, J. N. and Carl, S. A.: OH Formation in the Photoexcitation of $\mathrm{NO}_{2}$ beyond the Dissociation Threshold in the Presence of Water Vapor, J. Phys. Chem. A, 101, 4178-4184, 1997.

Daum, P. H., Kleinman, L. I., Springston, S. R., Nunnermacker, L. J., Lee, Y.-N., Weinstein-Lloyd, J., Zheng, J., and Berkowitz, C. M.: A comparative study of $\mathrm{O}_{3}$ formation in the Houston urban and industrial plumes during the 2000 Texas Air Quality Study, J. Geophys. Res., 108, 4715, doi:10.1029/2003JD003552, 2003.

Ensberg, J. J., Carreras-Sospedra, M., and Dabdub, D.: Impacts of electronically photo-excited $\mathrm{NO}_{2}$ on air pollution in the South Coast Air Basin of California, Atmos. Chem. Phys., 10, 11711181, doi:10.5194/acp-10-1171-2010, 2010.

Finlayson-Pitts, B. J., Wingen, L. M., Sumner, A. L., Syomin, D., and Ramazan, K. A.: The heterogeneous hydrolysis of $\mathrm{NO}_{2}$ in laboratory systems and in outdoor and indoor atmospheres: and integrated mechanism, Phys. Chem. Chem. Phys., 5, 223-242, 2003.

Foley, K. M., Roselle, S. J., Appel, K. W., Bhave, P. V., Pleim, J. E., Otte, T. L., Mathur, R., Sarwar, G., Young, J. O., Gilliam, R. C., Nolte, C. G., Kelly, J. T., Gilliland, A. B., and Bash, J. O.: Incremental testing of the Community Multiscale Air Quality (CMAQ) modeling system version 4.7, Geosci. Model Dev., 3, 205-226, doi:10.5194/gmd-3-205-2010, 2010.

George, C., Sterkowski, R. S., Kleffmann, J., Stemmler, K., and Ammann, M.: Photoenhanced uptake of gaseous $\mathrm{NO}_{2}$ on solid organic compounds: a photochemical source of HONO?, Faraday Discuss., 130, 195-210, 2005.

Grell, G. A., Dudhia, J., and Stauffer, D. R.: A description of the Fifth-Generation Penn State/NCAR Mesoscale Model (MM5), NCAR Technical Note, NCAR/TN - 398 + STR, 122 pp., available at: http://www.mmm.ucar.edu/mm5/, 1994.

Houyoux, M., Vukovich, J., and Brandmeyer, J.: Sparse Matrix Kernel Emissions Modeling System: SMOKE User Manual, MCNC- 
North Carolina Supercomputing Center, available at: http://www. cmascenter.org/, 2000.

Kirchstetter, T. W., Harley, R. A., and Littlejohn, D.: Measurements of nitrous acid in motor vehicle exhaust, Environ. Sci. Technol., 30, 2843-2849, 1996.

Kleffmann, J.: Daytime Sources of Nitrous Acid (HONO) in the Atmospheric Boundary Layer, Chem. Phys. Chem., 8, 1137-1144, doi:10.1002/cphc.200700016, 2007.

Kleffmann, J., Becker, K. H., and Wiesen, P.: Heterogeneous $\mathrm{NO}_{2}$ conversion processes on acid surfaces: possible atmospheric implications, Atmos. Environ., 32, 2721-2729, 1998.

Kleffmann, J., Gavriloaiei, T., Hofzumahaus, A., Holland, F., Koppmann, R., Rupp, L., Schlosser, E., Siese, M., and Wahner, A.: Daytime formation of nitrous acid: A major source of $\mathrm{OH}$ radicals in a forest, Geophys. Res. Lett., 32, L05818, doi:10.1029/2005GL022524, 2005.

Kurtenbach, R., Becker, K. H., Gomes, J. A. G., Kleffmann, J., Lörzer, J. C., Spittler, M., Wiesen, P., Ackermann, R., Geyer, A., and Platt, U.: Investigations of emissions and heterogeneous formation of HONO in a road traffic tunnel, Atmos. Environ., 35, 3385-3394, 2001.

Lammel, G. and Cape, J. N.: Nitrous acid and nitrate in the atmosphere, Chem. Soc. Rev., 25, 361-369, 1996.

Li, S., Matthews, J., and Sinha, A.: Atmospheric Hydroxyl Radical Production from Electronically Excited $\mathrm{NO}_{2}$ and $\mathrm{H}_{2} \mathrm{O}$, Science, 319, 1657-1660, 2008.

Li, S., Matthews, J., and Sinha, A.: Response to Comment on "Atmospheric Hydroxyl Radical Production from Electronically Excited $\mathrm{NO}_{2}$ and $\mathrm{H}_{2} \mathrm{O}$ ", Science, 324, 336, doi:10.1126/science.1166877, 2009.

Li, G., Lei, W., Zavala, M., Volkamer, R., Dusanter, S., Stevens, P., and Molina, L. T.: Impacts of HONO sources on the photochemistry in Mexico City during the MCMA-2006/MILAGO Campaign, Atmos. Chem. Phys., 10, 6551-6567, doi:10.5194/acp-106551-2010, 2010.

Li, X., Brauers, T., Häseler, R., Bohn, B., Fuchs, H., Hofzumahaus, A., Holland, F., Lou, S., Lu, K. D., Rohrer, F., Hu, M., Zeng, L. M., Zhang, Y. H., Garland, R. M., Su, H., Nowak, A., Wiedensohler, A., Takegawa, N., Shao, M., and Wahner, A.: Exploring the atmospheric chemistry of nitrous acid (HONO) at a rural site in Southern China, Atmos. Chem. Phys., 12, 1497-1513, doi:10.5194/acp-12-1497-2012, 2012.

Mao J., Ren X., Chen S., Brune W. H., Chen Z., Martinez M., Harder H., Lefer B., Rappenglück B., Flynn J., and Leuchner M.: Atmospheric Oxidation Capacity in the Summer of Houston 2006: Comparison with Summer Measurements in Other Metropolitan Studies, Atmos. Environ., 44, 4107-4115, doi:10.1016/j.atmosenv.2009.01.013, 2010.

Monge, M. E., D’Anna, B., Mazri, L., Giroir-Fendler, A., Ammann, M., Donaldson, D. J., and George, C.: Light changes the atmospheric reactivity of soot, P. Natl. Acad. Sci., 107, 6605-6609, 2010.

Ndour, M., D’Anna, B., George, C., Ka, O., Balkanski, Y., Kleffmann, J., Stemmler, K., and Ammann, M.: Photoenhanced uptake of $\mathrm{NO}_{2}$ on mineral dust: Laboratory experiments and model simulations, Geophys. Res. Lett., 35, L05812, doi:10.1029/2007GL032006, 2008.

Ngan, F., Byun, D. W., Kim, H. C., Rappenglück, B., and Pour-Biazar, A.: Performance Assessment of Retrospec- tive Meteorological Inputs for Use in Air Quality Modeling during TexAQS 2006, Atmos. Environ., 54, 86-96, doi:10.1016/j.atmosenv.2012.01.035, 2012.

Pagsberg, P., Bjergbakke, E., Ratajczak, E., and Sillesen, A.: Kinetics of the gas phase reaction $\mathrm{OH}+\mathrm{NO}(+\mathrm{M}) \rightarrow \mathrm{HONO}(+\mathrm{M})$ and the determination of the UV absorption cross section of HONO, Chem. Phys. Lett., 272, 383-390, 1997.

Rappenglück B., Perna, R., Zhong, S., and Morris, G. A.: An Analysis of the Vertical Structure of the Atmosphere and the Upper-Level Meteorology and their Impact on Surface Ozone Levels in Houston, Texas, J. Geophys. Res., 113, D17315, doi:10.1029/2007JD009745, 2008.

Rappenglück, B., Lefer, B., Wang, W.-Y., Czader, B., Li, X., Golovko, J., Alvarez, S., Flynn, J., Haman, C., and Grossberg, N.: University of Houston Moody Tower 2010 Ozone Formation Research Monitoring, Report to the Texas Commission on Environmental Quality, Project Grant No. 582-5-64594-FY10-14, August 2011, 98 pp., 2011

Rohrer, F., Bohn, B., Brauers, T., Brüning, D., Johnen, F.-J., Wahner, A., and Kleffmann, J.: Characterisation of the photolytic HONO-source in the atmosphere simulation chamber SAPHIR, Atmos. Chem. Phys., 5, 2189-2201, doi:10.5194/acp-5-21892005, 2005.

Sarwar, G., Roselle, S. J., Mathur, R., Appel, W., Dennis, R. L., and Vogel, B.: A comparison of CMAQ HONO predictions with observations from the Northeast Oxidant and Particle Study, Atmos. Environ., 42, 5760-5770, 2008.

Sörgel, M., Regelin, E., Bozem, H., Diesch, J.-M., Drewnick, F., Fischer, H., Harder, H., Held, A., Hosaynali-Beygi, Z., Martinez, M., and Zetzsch, C.: Quantification of the unknown HONO daytime source and its relation to $\mathrm{NO}_{2}$, Atmos. Chem. Phys., 11, 10433-10447, doi:10.5194/acp-11-10433-2011, 2011.

Stemmler, K., Ammann, M., Donders, C., Kleffmann, J., and George, C.: Photosensitizied reduction of nitrogen dioxide on humic acid as a source of nitrous acid, Nature, 440, 195-198, 2006.

Stemmler, K., Ndour, M., Elshorbany, Y., Kleffmann, J., D’Anna, B., George, C., Bohn, B., and Ammann, M.: Light induced conversion of nitrogen dioxide into nitrous acid on submicron humic acid aerosol, Atmos. Chem. Phys., 7, 4237-4248, doi:10.5194/acp-7-4237-2007, 2007.

Stutz, J., Oh, H.-J., Whitlow, S. I., Anderson, C. H., Dibb, J. E., Flynn, J., Rappenglück, B., and Lefer B.: Simultaneous DOAS and Mist-Chamber IC measurements of HONO in Houston, TX, Atmos. Environ., 44, 4090-4098, doi:10.1016/j.atmosenv.2009.02.003, 2010.

Su, H., Cheng, Y. F., Shao, M., Gao, D. F., Yu, Z. Y., Zeng, L. M., Slanina, J., Zhang, Y. H., and Wiedensohler, A.: Nitrous acid (HONO) and its daytime sources at a rural site during the 2004 PRIDE-PRD experiment in China, J. Geophys. Res., 113, D14312, doi:10.1029/2007JD009060, 2008.

Su, H., Cheng, Y., Oswald, R., Behrendt, T., Trebs, I., Meixner, F. X., Andreae, M. O., Cheng, P., Zhang, Y., and Pöschl, U.: Soil nitrite as a source of atmospheric $\mathrm{HONO}$ and $\mathrm{OH}$ radicals, Science, 333, 1616-1618, 2011.

Wennberg, P. O. and Dabdub, D.: Rethinking Ozone Production, Science, 319, 1624-1625, 2008.

Wilczak, J. M., Djalalova, I., McKeen, S., Bianco, L., Bao, J.W., Grell, G., Peckham, S., Mathur, R., McQueen, J., and Lee, 
P.: Analysis of regional meteorology and surface ozone during the TexAQS II field program and an evaluation of the NMMCMAQ and WRF-Chem air quality models, J. Geophys. Res., 114, D00F14, doi:10.1029/2007JD009060, 2009.

Wojtal, P., Halla, J. D., and McLaren, R.: Pseudo steady states of HONO measured in the nocturnal marine boundary layer: a conceptual model for HONO formation on aqueous surfaces, Atmos. Chem. Phys., 11, 3243-3261, doi:10.5194/acp-11-32432011, 2011.

Wong, K. W., Oh, H.-J., Lefer, B. L., Rappenglück, B., and Stutz, J.: Vertical profiles of nitrous acid in the nocturnal urban atmosphere of Houston, TX, Atmos. Chem. Phys., 11, 3595-3609, doi:10.5194/acp-11-3595-2011, 2011.

Wong, K. W., Tsai, C., Lefer, B., Haman, C., Grossberg, N., Brune, W. H., Ren, X., Luke, W., and Stutz, J.: Daytime HONO vertical gradients during SHARP 2009 in Houston, TX, Atmos. Chem. Phys., 12, 635-652, doi:10.5194/acp-12-635-2012, 2012.
Yu, Y., Galle, B., Panday, A., Hodson, E., Prinn, R., and Wang, S.: Observations of high rates of $\mathrm{NO}_{2}-\mathrm{HONO}$ conversion in the nocturnal atmospheric boundary layer in Kathmandu, Nepal, Atmos. Chem. Phys., 9, 6401-6415, doi:10.5194/acp-9-6401-2009, 2009.

Zhou, X. L., He, Y., Huang, G., Thornberry, T. D., Carroll, M. A., and Bertman, S. B.: Photochemical production of nitrous acid on glass sample manifold surfaces, Geophys. Res. Lett., 29, 1681, doi:10.1029/2002GL015080, 2002.

Zhou, X. L., Gao, H. L., He, Y., Huang, G., Bertman, S. B., Civerolo, K., and Schwab, J.: Nitric acid photolysis on surfaces in low- $\mathrm{NO}_{\mathrm{x}}$ environments: significant atmospheric implications, Geophys. Res. Lett., 30, 2217, doi:10.1029/2003GL018620, 2003.

Ziemba, L. D., Dibb, J. E., Griffin, R. J., Anderson, C. H., Whitlow, S. I., Lefer, B. L., Rappenglück, B., and Flynn, J.: Heterogeneous conversion of nitric acid to nitrous acid on the surface of primary organic aerosol in an urban atmosphere, Atmos. Environ., 44, 4081-4089, doi:10.1016/j.atmosenv.2008.12.024, 2010. 